Original Research Paper

\title{
Meningkatkan Kemampuan Hafalan Al-Quran Anak-anak Melalui Kegiatan Taman Pendidikan Al-Quran di Desa Nijang Kabupaten Sumbawa Besar
}

\author{
Napiah $^{1 *}$, Agil Al Idrus ${ }^{2}$ \\ ${ }^{I}$ Program Studi Pendidikan Pancasila \& Kewarganegaraan, Fakultas Keguruan dan Ilmu Pendidikan, Universitas Mataram, \\ Mataram, Indonesia \\ ${ }^{2}$ Program Studi Pendidikan Biologi, Fakultas Keguruan dan Ilmu Pendidikan, Universitas Mataram, Mataram, Indonesia
}

DOI: https://doi.org/10.29303/jpmpi.v3i2.591

Sitasi: Sari, N., \& Idrus, A. A. (2021). Meningkatkan Kemampuan Hafalan Al-Quran Anak-anak Melalui Kegiatan Taman Pendidikan Al-Quran di Desa Nijang Kabupaten Sumbawa Besar. Jurnal Pengabdian Magister Pendidikan IPA, $4(1)$

\author{
Article history \\ Received: 02 Desember 2020 \\ Revised: 29 Desember 2020 \\ Accepted: 18 Januari 2021 \\ *Corresponding Author: \\ Napiah, Program Studi \\ Pendidikan Pancasila \& \\ Kewarganegaraan, Fakultas \\ Keguruan dan Ilmu Pendidikan, \\ Universitas Mataram, Mataram, \\ Indonesia \\ Email: fiifia1598@gmail.com
}

\begin{abstract}
Menghafalkan al-Quran merupakan aktivitas suatu proses menempatkan informasi kedalam memori ingatan. Menghafal al-Quran tentunya tidak serta merta di mulai tanpa melalui proses pembelajaran dasar-dasar al-Quran. Memplajari al-Quran tentunya di awali dengan mengenal huruf- huruf sampai pada kemampuan membaca al-Quran dengan tajwidnya. Untuk menciptakan generasi anak yang cinta terhadap al-Quran tentunya al-Quran di awali dengan anak-anak. Tujuan memperkenalkan alQuran kepada anak-anak tidak lain untuk mencintai al-Quran, terbiasa membaca al-Quran, menerapkan bacaan al-Quran bagi anak-anak dalam kehidupan sehari-hari. Metode yang digunakan ialah metode fun learning dan metode demonstrasi. Dengan meningkatkan hafalan al-Quran anak di masa mendatang mampu menciptakan generasi yang cinta terhadap alQuran.
\end{abstract}

Keywords: Meningkatkan hafalan al-Quran; Metode fun learning

\section{Pendahuluan}

Menghafal al-quran merupakan aktivitas suatu proses menempatkan informasi kedalam memori ingatan. Sehingga sebagai orang islam wajib membaca, menghafalkan,memahami dan menerapkan dalam kehidupan sehari-hari. Menghafal al-Quran membutuhkan proses. Oleh sebab itu langkah awal untuk menghafal al-quran di berikan kepada anak usia dini. Pada hakikatnya anak-anak memilki daya ingat yang kuat apalagi berhubungan langsung dengan anak melalui pengalaman yang dilihat dan yang terjadi di lingkungan anak. Dengan tujuan kegiatan menghafal al-quran diberikan kepada anak-anak untuk membiasakan anak beribadah, membaca alQuran, menghafal dan mengamalkan isi al-Quran untuk kehidupan sehari-hari.
Di tengah pesatnya kemajuan teknologi di masa pandemic covid-19 ini sangat berpengaruh terhadap perilaku anak-anak. Apabila anak-anak diberikan kebebasan dalam teknologi oleh orang tua, maka akibat yang akan terjadi di masa yang akan datang anak-anak tidak lagi terbiasa dalam membaca al-Quran maupun tidak lancar dalam melafadzkan al-Quran.

Selama peniliti mengamati di lapangan ternyata anak-anak di berikan mengenal sebuah teknologi bahkan memiliki handphone sendiri. Oleh sebab itu peneliti melakukan program TPQ kepada anak-anak agar tingkatan hafalan anak-anak semakin lancar serta terbiasa dalam membaca alQuran. Sehingga seimbang dalam berkembang dengan teknologi dan tidak lupa pula dengan membaca al-Quran. Selain itu tujuan program TPQ di desa Nijang bertujuan meningkatkan hafalan anak-anak, meningkatkan bacaan al-Quran anak- 
anak dan terbiasa dalam membaca al-Quran. Selama berjalannya program TPQ di desa Nijang tentunya ada metode dalam mengajar yang mampu menarik anak-anak dalam belajar TPQ. Metode yang di gunakan yaitu fun learning.

\section{Metode}

Penelitian ini menggunakan pendekatan kualitatif dan metode yang digunakan selama mengajar di rumah ilmu dengan metode demonstrasi dan metode fun learning. Data- data yang di ambil dari anak paud, anak sd kelas 1 sampai 3.

\section{Hasil dan Pembahasan}

Hasil penelitian yang di peroleh dari lapangan ialah pelaksanaan dalam mengajar anakanak menghafal al-Quran melalui kegiatan TPQ. Mengajari anak-anak tentunya memilki metode yang menarik agar anak-anak memilki motivasi dalam menghafalkan ayat-ayat al-Quran. Metode yang digunakan oleh peneliti yaitu metode demonstrasi.

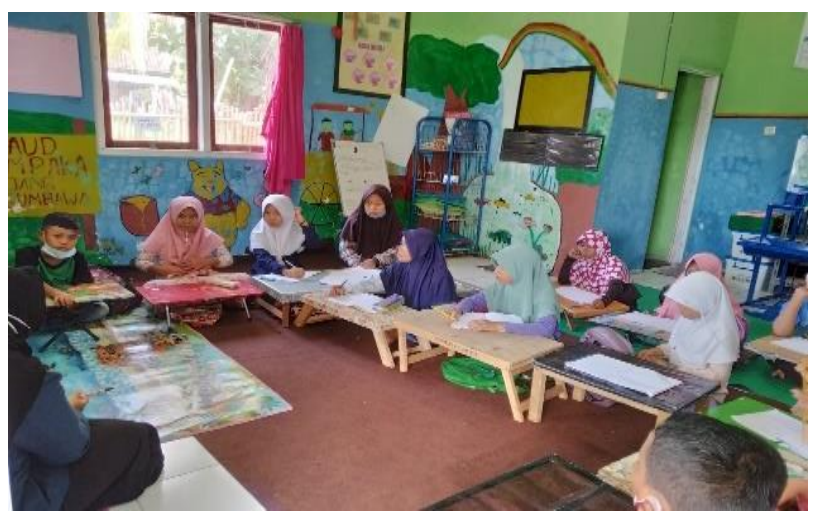

Gambar 1. Mahasiswa Mengajar Dengan Metode Demonstrasi

Menurut drajat metode demonstrasi merupakan metode yang menggunakan peragaan untuk memperjelas atau pengertian atau memperlihatkan bagaimana melakukan sesuatu kepada peserta lain. Demonstrasi merupakan pembelajaran yang efektif, karena anak- anak dapat mengetahui secara langsung penerapan materi tersebut dalam kehidupan sehari-hari. Artinya metode pembelajaran demonstrasi adalah cara penyajian pembelajaran dengan meragakan dan mempertunjukkan suatu proses, situasi atau benda tertentu yang sedang di pelajari baik bentuk sebenarnya maupun bentuk tiruan yang di pertunjukkan oleh guru atau sumber belajar lain di depan seluruh siswa.

Dengan metode demonstarsi ini mempermudah anak-anak dalam menghafalkan ayat-ayat pendek ataupun al-Quran. Sebab cara demonstarsi ini di awali oleh peniliti terlebih dahulu untuk menyebutkan ayat-ayat pendek yang akan di ikuti oleh anak-anak tersebut.

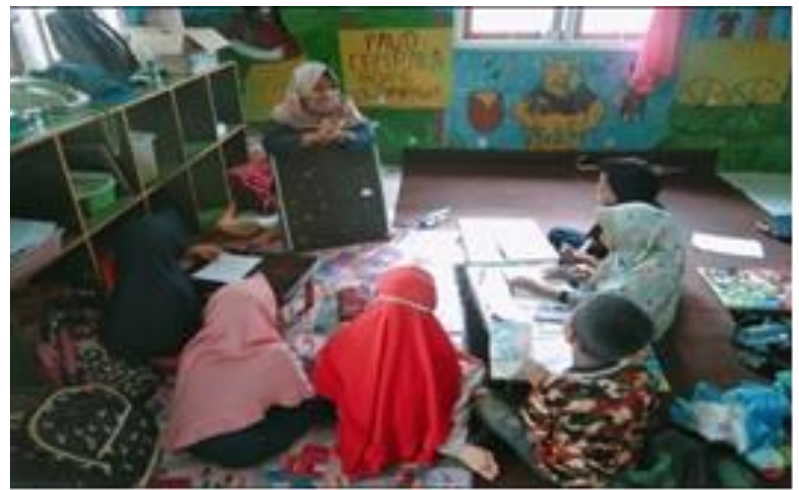

Gambar 2. Mahasiswa menjelaskan materi terkait ayatayat pendek

Selain menggunakan metode demonstrasi kepada anak-anak, peneliti menggunakan metode fun learning. Fun learning atau cara belajar yang menyenangkan dan mengasikkan menurut pendidik komunitas sekolah alam adalah suatu proses belajar yang mengangkat kehidupan secara naturan dan riil serta indah dan nyaman. Proses pembelajaran ini menjadi sebuah aktivitas kehidupan riil yang di hayati dengan penuh kegembiraan.

Menurut Tolstoy (Freire,2004:429) belajar yang menyenangkan sangat perlu dalam proses pembelajaran karena sangat membantu bagi peserta didik untuk bisa menjadikan bahan pelajaran menjadi bermakna, memberi motivasi belajar, dan menyediakan kepuasan belajar. Karena belajar yang menyenangkan akan membuat anak merasa tidak di bebani atau tidak dipaksa untuk belajar.

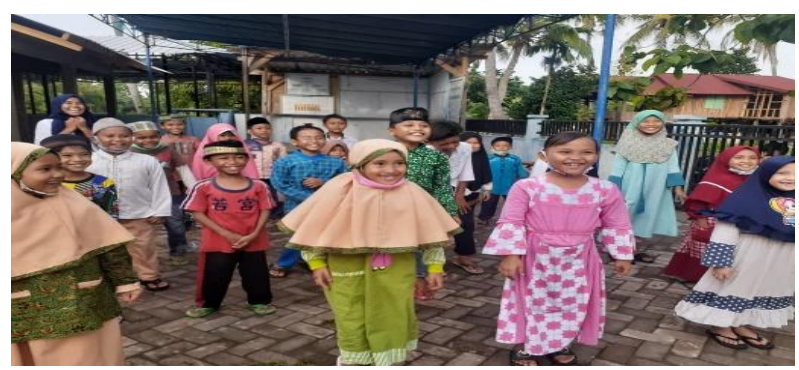

Gambar 3. Metode Fun Learning 
Selama kegiatan program TPQ berlangsung menggunakan 2 metode dalam mengajar anak-anak. Metode demonstrasi bertujuan dalam penyampaian materi terkait ayat-ayat pendek yang dapat memudahkan anak-anak paham serta cepat tanggap terhadap materi yang di jelaskan. Sedangkan metode fun learning membuat suasana lebih menyenangkan saat anak-anak mencoba dalam menghafalkan ayat-ayat pendek agar anak-anak tidak memiliki beban dalam mencoba menghafalkan ayat-ayat pendek tersebut. Penerapan metode ini membantu anak-anak dalam proses pembelajaran sehingga mampu menarik kemampuan anak-anak.

Adapun materi yang diberikan kepada anak-anak untuk menguji suatu tingkatan kemampuan anak-anak ialah materi tentang suratsurat pendek. Pada tahap pertama mengenai surat al lahab. Pembacaan surat al lahab di awalai oleh peneliti sendiri agar mampu menarik anak mengikuti. Hasilnya anak-anak bersemangat ingin mempelajari ataupun menghafalkannya. Selama kegiatan belajar berlangsung anak-anak mulai meningkatkan kemampuan hafalan al-Quran dengan suasana yang fun learning. Serta anak-anak bersemangat mempelajari tajwid serta kumpulan doa-doa.

Pada tahap selanjutnya untuk mengukur peningkatan hafalan anak-anak peneliti mengadakan perlombaan yang di ikuti oleh beberapa anak PAUD, SD kelas 1-3 dengan jumlah keseluruhan peserta lomba yaitu 25 anak-anak.

Selama tahap perlombaan menggunakan metode undian yang akan di ambil oleh setiap peserta. Tujuan metode undian ini melatih tingkatan hafalan atau daya ingat anak-anak yang telah di pelajari sebelumnya. Berdasarkan penilaian serta pengamatan bahwa anak-anak mamilki kemampuan daya ingat yang tinggi dalam menghafalkan ayatayat pendek yang telah di pelajari. Meningkatkan kemampuan anak dalam menghafalkan ayat-ayat pendek ini memberikan hasil yang meningkat atau positif melalui kegiatan TPQ dengan metode demonstrasi dan metode fun learning. Memberikan pelajarajan hafalan al-Quran kepada anak-anak di tahap awal memberikan tingkatan yang baik dalam memori ingatan.

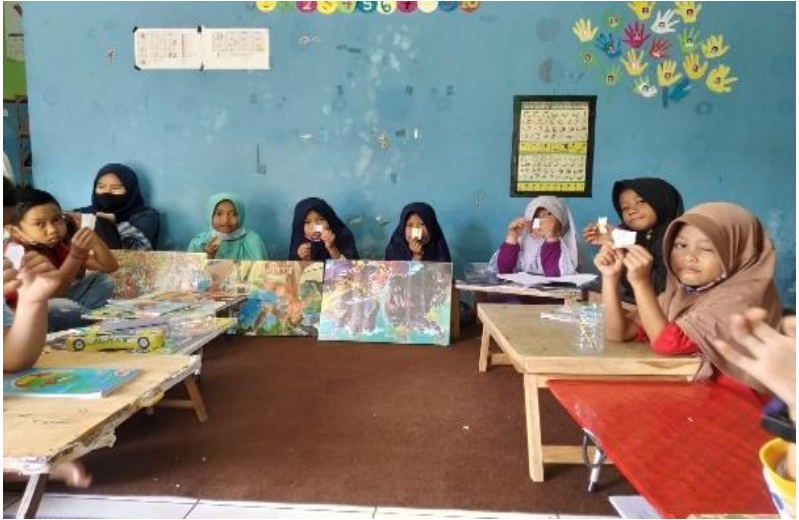

Gambar 4. Menghafal ayat- ayat pendek dengan cara undian

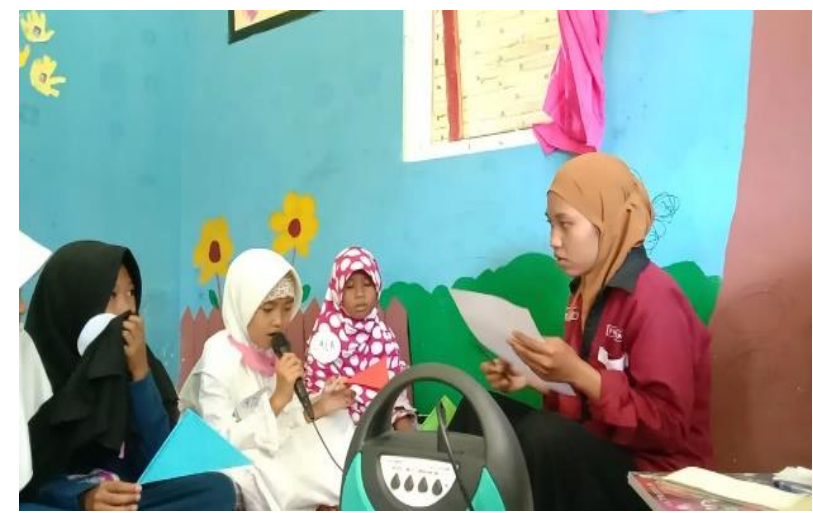

Gambar 5. Acara perlombaan menghafal ayat-ayat pendek

\section{Kesimpulan}

Menghafal al-quran merupakan aktivitas suatu proses menempatkan informasi kedalam memori ingatan. Sehingga sebagai orang islam wajib membaca, menghafalkan, memahami dan menerapkan dalam kehidupan sehari-hari. Untuk meningkatkan hafalan anak-anak di perlukan metode yang baik bagi anak-anak. Sebelum menerapkan metode yang di gunakan, terlebih dahulu mengenali apa saja permasalahan yang terjadi oleh anak-anak. Berdasarkan hasil penelitian bahwa anak-anak di desa Nijang memilki kemampuan dalam menghafalkan ayat-ayat alQuran dengan metode fun learning yang merupakan yang disukai oleh anak-anak sehingga mampu membantu mengatasi permasalahan anak-anak di desa Nijang. 


\section{Ucapan Terima Kasih}

Terima kasih kepada dosen pembimbing Prof. Dr. Agil Al Idrus, M.Si yang telah membimbing kami dalam proses pelaksanaan penyusunan paper dari hasil kegiatan KKN di Desa Nijang. Selanjutnya kepada bapak kepala desa atas segala bimbingannya dan pihak-pihak yang terkait lainnya yang senantiasa selalu memberikan dukungan dalam terlaksananya kegiatan KKK ini.

\section{Daftar Pustaka}

Indra Kaswara. 2017. Pengelolaan pembelajaran Tahfidzul Quran di Pondok Pesantren Al Husain Magelang. Jurnal Hanata Wijaya. Universitas Negeri Yogyakarta. Vol 6 nomor 2.

Purwanto, 1990. Psikologi Pendidikan. Bandung : PT Remaja Rasdakarya.

Leni Layyinah. 2017. Menciptakan Pembelajaran fun learning based on scientific dalam pembentukan karakter peserta didik pada pembelajaran pai. Tarbawy. Vol,4, nomor 1.

Mulyasa, E. 2007. Menjadi Guru Profesional Menciptakan Pembelajaran Kreatif dan Menyenangkan. Bandung: Rosda karya.

Darmasya. 2011. Strategi Pembelajaran dengan Humor. Jakarta: Bumi Aksara

Djamara, S.B. 2010. Guru dan Anak Didik Dalam Interaksi Edukatif. Jakarta: Rineka Cipta.

Miftahul Huda. 2013. Model-Model Pengajaran dan Pembelajaran. Yogyakarta: Pustaka Belajar.

Maerani Agustina dkk. 2020. Strategi Peningkatan Minat Menghafal Al-Quran Santri Pondok Pesantren Ar Rahman Curup. Didaktika:jurnal Pendidikan. Vol. 14 no 1.

Susianti, C. 2017. Efektivitas Metode Talaki Dalam Meningkatkan Kemampuan Menghafal AlQuran anak usia dini. Tunas Siliwangi: Jurnal Program Studi Pendidikan Guru PAUD STKIP Siliwangi Bandung, 2(1), 68-78. 